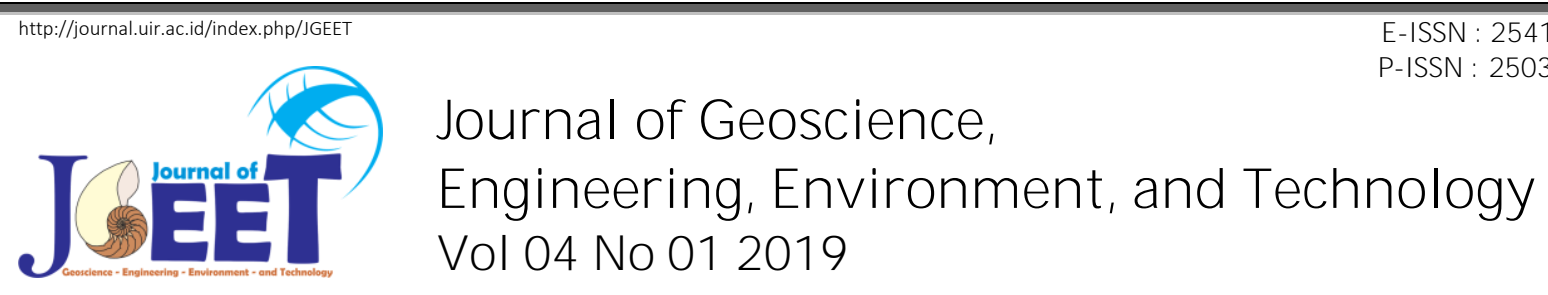

RESEARCH ARTICLE

\title{
Hydrogeochemical and Groundwater Assessment for Drinking Purpose at ITERA Campus Area and Its Surroundings
} Luhut Pardamean Siringoringo ${ }^{1}$, , Reza Rizki ${ }^{1}$, Janner Nababan ${ }^{2}$

${ }^{1}$ Institut Teknologi Sumatera, Jl. Terusan Ryacudu, Kecamatan Jati Agung, Lampung Selatan 35365, Indonesia. ${ }^{2}$ Balai Konservasi Airtanah, Badan Geologi, Kementerian Energi dan Sumber Daya Mineral, Indonesia.

* Corresponding author : luhut.pardamean@gl.itera.ac.id

Received: Des 26, 2018; Accepted: Feb 20, 2019.

DOI: 10.25299/jgeet.2019.4.1.2478

\begin{abstract}
The total population around ITERA has increased every year as students acceptance every year. To anticipate this, it needs to be done a research at ITERA campus and its surrounding about the quality of groundwater for drinking purpose and the hydrogeochemical of groundwater to know the controlling factors which are dominant. The methods are integrating Piper diagram plotting result, $X-Y$ plotting result for some cations and anions, and Gibbs diagram plotting result. It is for hydrogeochemical analysis. Groundwater assessment for drinking purpose referred to Peraturan Menteri Kesehatan Republik Indonesia No. 492/MENKES/PER/IV/2010. There were 14 samples that were taken from nine dig wells and five drill wells. The groundwater facieses were dominated by Facies $\mathrm{Na}-\mathrm{HCO}_{3}-\mathrm{Cl}\left(35,71 \%\right.$ followed by Facies $\mathrm{Na}-\mathrm{Cl}\left(21,43 \%\right.$, Facies $\mathrm{Na}-\mathrm{HCO}_{3}$ $\left(21,43 \%\right.$, Facies Na-SO$-\mathrm{Cl}(14,29 \%)$, dan Facies $\mathrm{Ca}-\mathrm{Mg}-\mathrm{HCO}_{3}(7,14 \%)$. Groundwater hydrogeochemical of research area shows that groundwater chemistries are controlled by minerals weathering, evaporation, and precipitation. There are eight wells that not proper for drinking and six wells that proper for drinking. Integration lab result, stratigraphic analysis, and depth aquifer show that groundwater that proper for drinking comes from confined aquifer while that not proper for drinking comes from unconfined aquifer.
\end{abstract}

Keywords: Facies, Gibbs, Hydrogeochemical, Piper

\section{Introduction}

ITERA is a first new state technology institute at Sumatera. ITERA from 2014 till 2018 has been lecturing for about five thousand students. This number will be increasing as long as new students acceptance every year. The additional of amounts students will trigger economic growth, especially at campus surroundings. To anticipate economic growth in the future, research is very important to be done to understand groundwater hydrogeochemical characteristic of the research area and its proper to all needs especially for drinking water purpose (Chang and Wang, 2010; Wen et al., 2005). It is based on that water is the most important element in human health.

Groundwater chemistry composition depends on hydrogeochemical process that groundwater pass. Groundwater chemical compositions are integration natural and anthropogenic factors such as precipitation, oxidation-reduction between groundwater and mineral aquifers, geological structures, cation exchange, mineral dissolution, water mixing, fertilizer leaching, biology process, and human activities. All these interactions result in variations of groundwater type (Yang et al., 2016). Thus, hydrogeochemical study what types of process that control groundwater hydrochemistry (Jeevanandam et al., 2007).
The objects of research including groundwater from dig well, that could be called as groundwater from unconfined aquifer and groundwater from drill well, that could be called as groundwater from confined aquifer. The research purposes are to interpret hydrogeochemical processes that control groundwater chemistry composition and groundwater assessment for drinking purpose. This research might be the first research that ever been done at this research area. Hopefully, this research result could help local government to make policies about development area in the future.

\section{Geology and Hydrogeology}

Research area is included within Tanjungkarang sheet regional geology map scale 1:250.000 (Mangga, S.A; Amirudin; Suwarti, T; Gafoer, 1993). The area is composed of Lampung Formation of Quaternary age (fig 1). The Lampung formation is composed of pumice tuff, rhyolitic tuff, tuff unified tuffit, tuffaceous claystone, and tuffaceous sandstone. From this, all lithologies are volcanic activities associated. Lampung Formation is deposited unconformity above of Andesite of Tertiary age. At above of Lampung Formation is deposited unconformity young volcanic deposits (lava andesitebasalt, breccia, and tuff). Geological structures that have been developed so little or still unidentified. 
According to Kepres no 26, the year 2011, the research area is included within Metro-Kotabumi Groundwater Basin. It can be known from the location of research area within South Lampung Sub-Province Administratively. From hydrogeology perspective, research area is composed of tuff aquifer that locally productive (Setiadi, H., Ruhijat, 1993). It means not whole research area has high productivity to release water (low-medium break out).

\section{Research Methods}

The preliminary step in this research was prepared topless glass $2000 \mathrm{ml}$ which had been washed with liquid soap, motionless for several minutes, shaken, rinsed with sanitary water, dried, and if residual water still exists then be drained by dry tissue. These treatments also be used for $1000 \mathrm{ml}$ Polypropylene bottles as temporary storage media before groundwater samples were analyzed at lab (Badan Standarisasi Nasional, 2008). The topless glass only be used to took sample from dig well. Furthermore, the bottles were filled by this sample. If the samples were taken from drill well, the treatment would not use topless glass. In detail, the samples were directly taken using Polypropylene bottles one minute after the faucet be opened. This treatment was done for throwaway deposits during the water didn't drain. Next step samples were sent to Laboratorium Kualitas Air Fakultas Teknik Sipil dan Lingkungan ITB then be analyzed with Standard Methods for The Examination of Water and Wastewater $22^{\text {nd }}$ Edition 2012 (APHA).

Figure 1 shows the geological of research area is composed by Lampung Formation at the surface. The formation is composed of pumice tuff, rhyolitic tuff, tuff unified tuffit, tuffaceous claystone, and tuffaceous sandstone. It means the majority rocks were silicate rocks. This profile could be impacted to the chemical of groundwater, especially addition of $\mathrm{Na}$ and $\mathrm{K}$ ion to groundwater (Meybeck, 1987). The method to analyze how much geology and non geology aspects has been impacted to groundwater is integrating Piper diagram, $\mathrm{X}-\mathrm{Y}$ plotting ( $\mathrm{Ca}+\mathrm{Mg} / \mathrm{HCO}_{3}, \mathrm{Na}+\mathrm{K} / \mathrm{Ca}+\mathrm{Mg}, \mathrm{Na} / \mathrm{Cl}$, and $\left.\mathrm{Na}+\mathrm{Cl} / \mathrm{HCO}_{3}+\mathrm{SO}_{4}+\mathrm{Mg}-\mathrm{Ca}\right)$ and Gibbs plot $(\mathrm{Na} /(\mathrm{Na}+\mathrm{Ca})$ / TDS, $\mathrm{Cl} /\left(\mathrm{Cl}+\mathrm{HCO}_{3}\right)$ / TDS).

Groundwater assessment for drinking purpose using Indonesia Healthy Ministry regulation standard No. 492/MENKES/PER/IV/2010. The parameters are Smell, Flavor, Colour (Pt.Co), Muddiness (NTU), EC $(\mu \mathrm{S} / \mathrm{cm})$, TDS $(\mathrm{mg} / \mathrm{L})$, Temp $\left({ }^{\circ} \mathrm{C}\right)$, Fe $(\mathrm{mg} / \mathrm{L}), \mathrm{F}(\mathrm{mg} / \mathrm{L}), \mathrm{pH}$ $(\mathrm{mg} / \mathrm{L}), \mathrm{Mn}(\mathrm{mg} / \mathrm{L}), \mathrm{NO}_{3}(\mathrm{mg} / \mathrm{L}), \mathrm{NO}_{2}(\mathrm{mg} / \mathrm{L}), \mathrm{Cl}(\mathrm{mg} / \mathrm{L})$, $\mathrm{SO}_{4}(\mathrm{mg} / \mathrm{L}), \mathrm{Na}(\mathrm{mg} / \mathrm{L}), \mathrm{CaCO}_{3}\left(\mathrm{mg} / \mathrm{L} \mathrm{CaCO}_{3}\right)$, and $\mathrm{Pb}$ (mg/L).

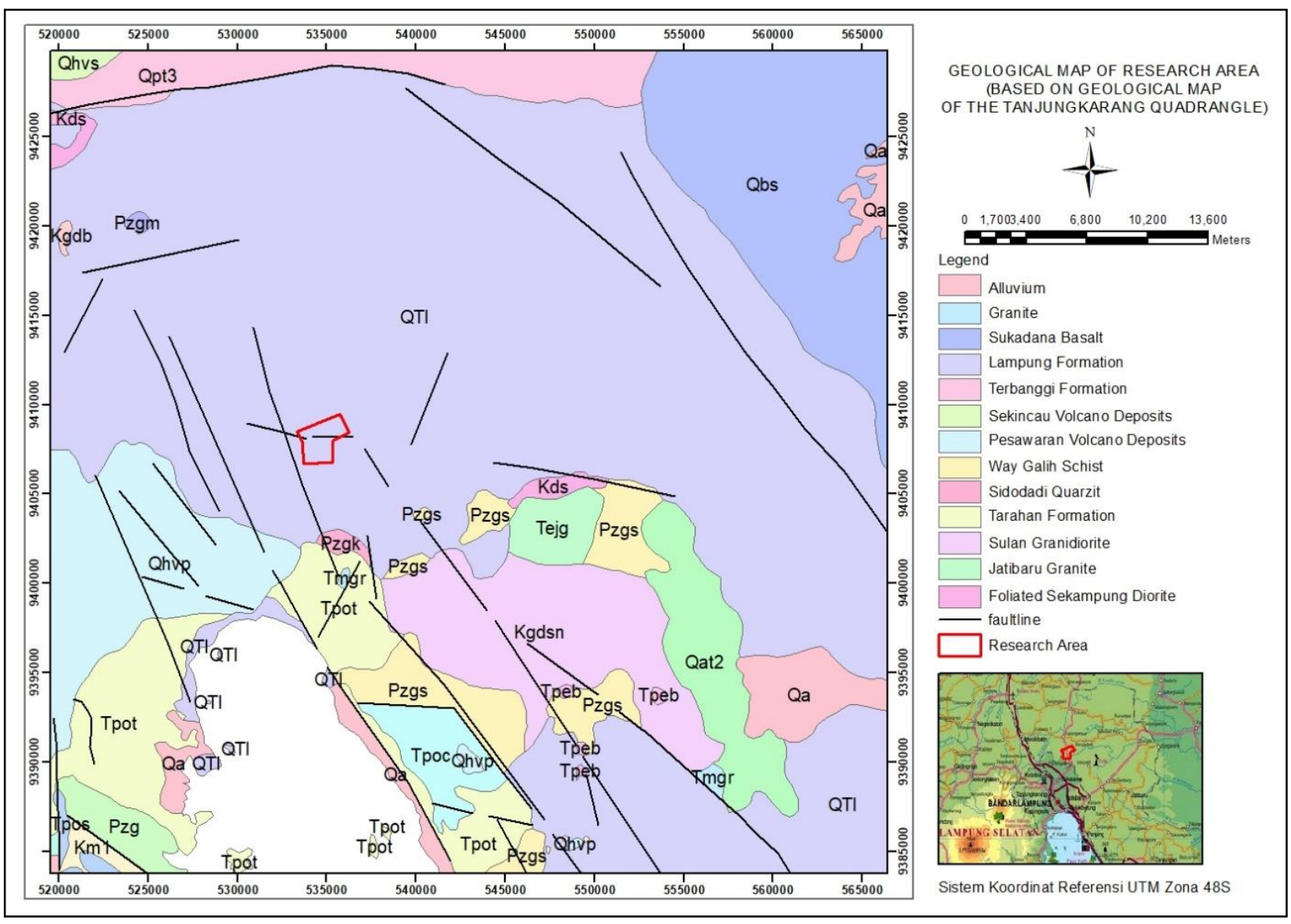

Fig. 1. Geological Map of research area (modified from Mangga, 1993). 


\section{Result and Discussion}

\subsection{Hydrogeochemical Study}

The groundwater observations had been conducted on 14 wells including nine dig wells and five drill wells (fig 2). All of nine dig wells having range water depth between $0,2 \mathrm{~m}-8,2 \mathrm{~m}$ which can be classified into unconfined aquifer (Table 1 ). While other five drill wells having well depth about $40 \mathrm{~m}$ and $80 \mathrm{~m}$ which can be classified into confined aquifer. It is also supported by previous research result that had been conducted at campus ITERA in 2017. The previous research was purposed to detect type of aquifer and its depth with Schlumberger configuration-geoelectrical method. This research concluded, stratigraphically, the rocks from younger to oldest are siltstone, claystone, sandstone, and claystone with depth aquifer at more than $25 \mathrm{~m}$ (Setiawan et al., 2017). If observed from rocks ability to storage, to release water and also connected to its position to upper rock layer and lower rock layer, then can be concluded that sandstone is confined aquifer.

Piper diagram is one of the most effective graphic representation in the study of the groundwater quality, which helps to understand the groundwater geochemical characteristics (Yang et al., 2016). Based on plotting data of cation and anion into Piper diagram, there are five hydrochemical facieses, they are $\mathrm{Na}$ $\mathrm{HCO}_{3}-\mathrm{Cl}(35,71 \%), \mathrm{Na}-\mathrm{Cl}(21,43 \%), \mathrm{Na}-\mathrm{HCO}_{3}(21,43 \%$, $\mathrm{Na}-\mathrm{SO} 4-\mathrm{Cl}\left(14,29 \%\right.$, and $\mathrm{Ca}-\mathrm{Mg}-\mathrm{HCO}_{3}(7,14 \%$ (fig 3$)$.

\subsection{Groundwater Assessment for Drinking Purpose}

Groundwater assessment for drinking purpose at research area is according to Indonesia Healthy Ministry regulation standard No. 492/MENKES/PER/IV/2010 (Table 2). There are 18 parameters which be used as references for this research. The 18 parameters including 7 physics and 11 chemical data. Laboratory analysis result shows there are value differences which very contrast on some parameters. The parameters are colour, muddiness, TDS, Fe, pH, $\mathrm{Mn}$, and $\mathrm{NO}_{3}$ (Table 3 and Table 4). These contrast differences in value are evidently out of standard range which had been set. These are occurred on some samples were $A 1, A 2, A 3, A 4, A 5, A 7, A 8, A 9$ (Table 5).

$\mathrm{X}-\mathrm{Y}$ plots are used to assess relative abundances of major cationic and anionic species present in different water environments (Pazand et al, 2018). There are four $X-Y$ plots that will be used for analyzing the effect of rocks to groundwater. They are $\mathrm{Na} / \mathrm{Cl}, \mathrm{Na}+\mathrm{K} / \mathrm{Ca}+\mathrm{Mg}$, $\mathrm{Ca}+\mathrm{Mg} / \mathrm{HCO}_{3}$, and $\mathrm{Na}+\mathrm{Cl} / \mathrm{HCO}_{3}+\mathrm{SO}_{4}+\mathrm{Mg}-\mathrm{Ca}$ (meq/l) graphic.

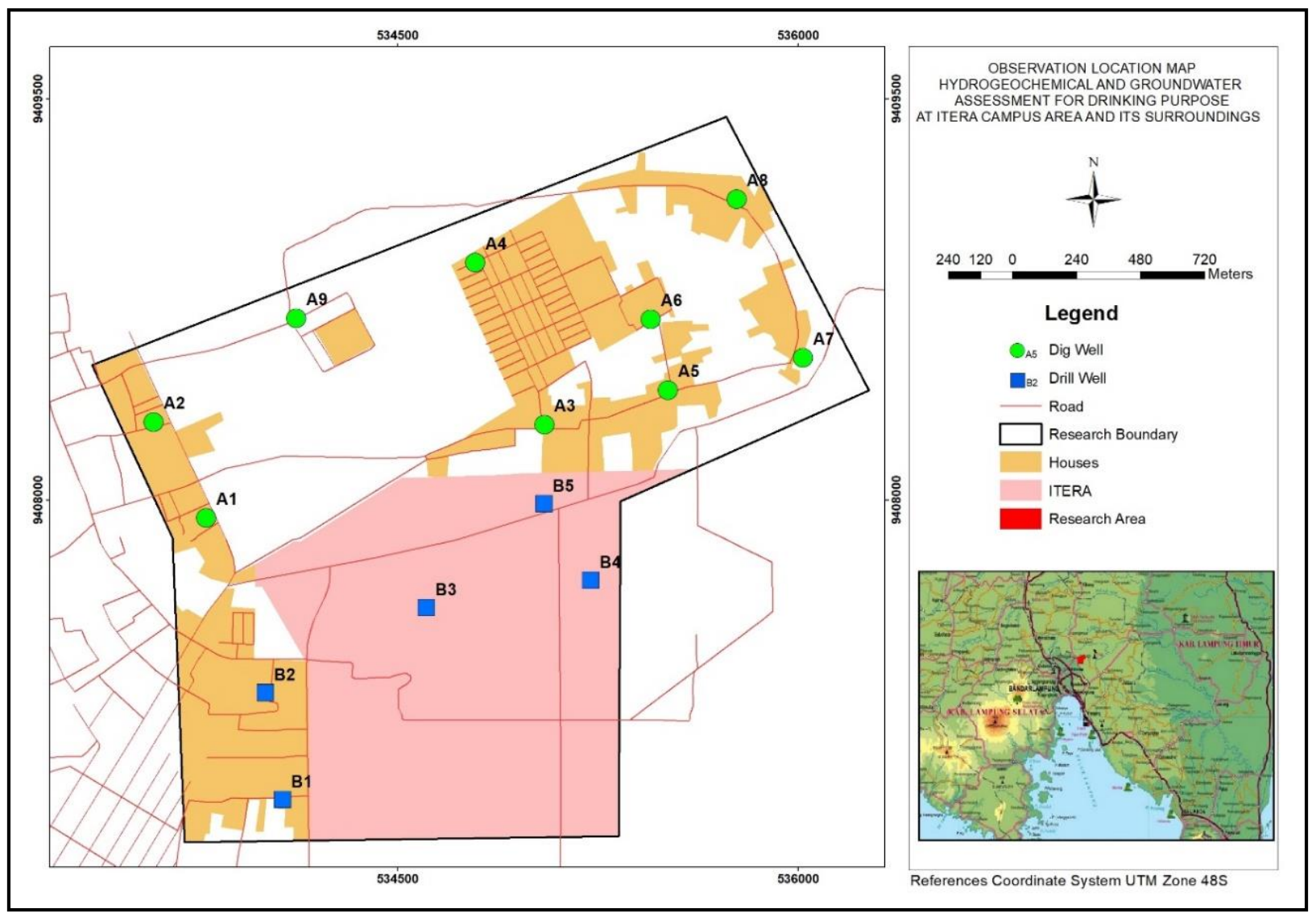

Fig. 2. The research area includes wells. 
Table 1. The Aquifer types of research area based on integration with previous research.

\begin{tabular}{llll}
\hline Samples Code & Wells Type & Water Depth & Aquifer Type \\
\hline A1 & Dig & 3 & unconfined aquifer \\
A2 & Dig & 5,45 & unconfined aquifer \\
A3 & Dig & 5,6 & unconfined aquifer \\
A4 & Dig & 0,2 & unconfined aquifer \\
A5 & Dig & 0,7 & unconfined aquifer \\
A6 & Dig & 1 & unconfined aquifer \\
A7 & Dig & 1,1 & unconfined aquifer \\
A8 & Dig & 0,2 & unconfined aquifer \\
A9 & Dig & 8,2 & unconfined aquifer \\
B1 & Drill & 40 & confined aquifer \\
B2 & Drill & 40 & confined aquifer \\
B3 & Drill & 80 & confined aquifer \\
B4 & Drill & 80 & confined aquifer \\
B5 & Drill & 80 & confined aquifer \\
\hline
\end{tabular}

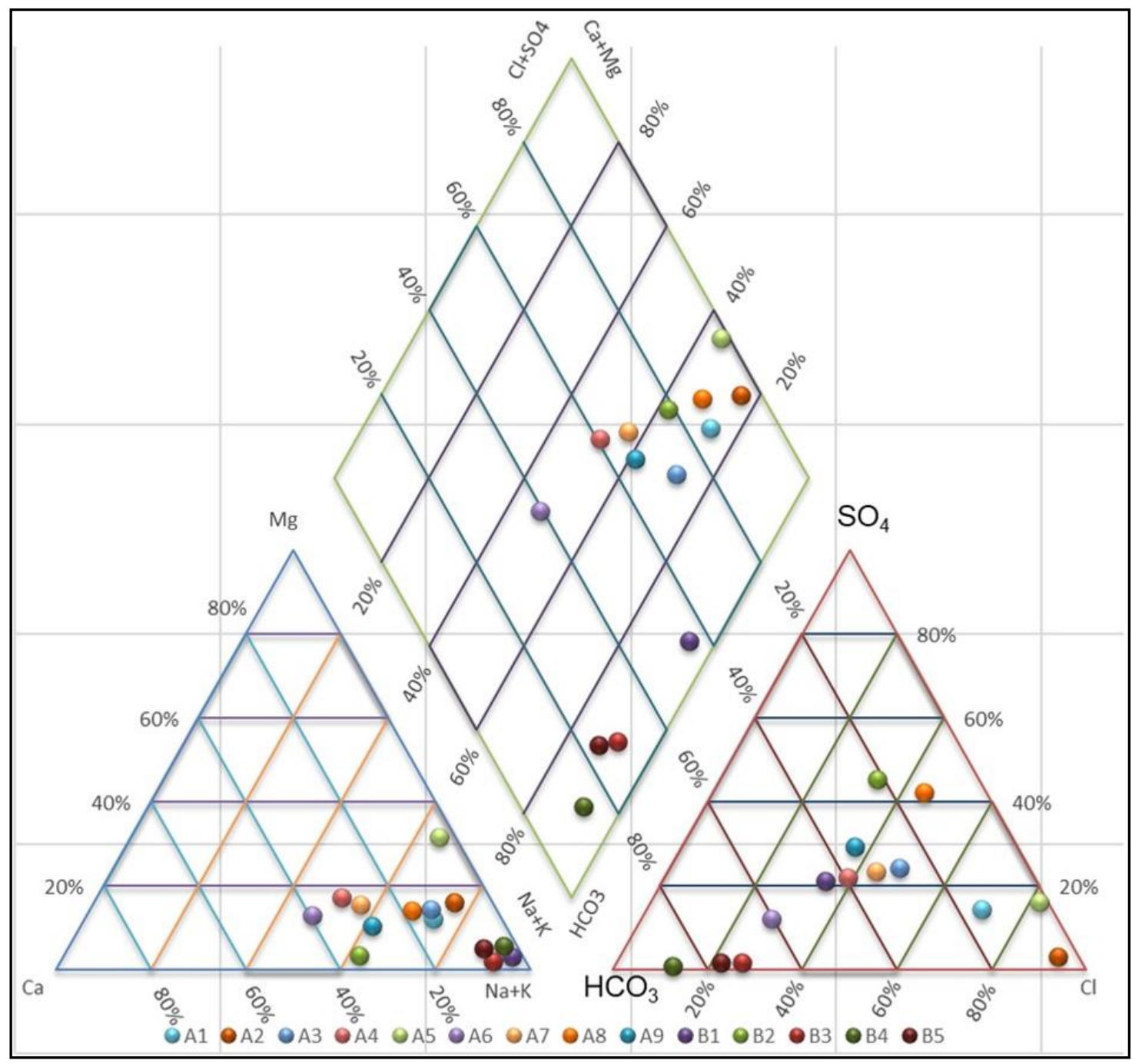

Fig. 3. Piper diagram of ionic compositions of groundwater in research area. 
$\mathrm{Na} / \mathrm{Cl}$ graphic is used to identify the mechanisms for acquiring salinity and saline intrusions in semiarid regions (Yang et al, 2016). $\mathrm{Na} / \mathrm{Cl}$ ratio is $>1$, indicating that weathering of silicate rocks such as granodiorite, andesite, rhyolite and tuff was the primary process responsible for the release of $\mathrm{Na}^{+}$into the groundwater. $\mathrm{Na} / \mathrm{Cl}$ ratio is $<1$, the ion exchange and/or evaporation were dominant process resulting in the addition of $\mathrm{Cl}^{-}$in the groundwater (M eybeck, 1987). Based on ion $\mathrm{Na}$ and $\mathrm{Cl}$ plotting into $\mathrm{Na} / \mathrm{Cl}$ graphic (fig 4a), could be known that the ratio is $>1$. This result shows that the ion $\mathrm{Na}$ comes from the weathering of silicate rocks.

The $\left(\mathrm{Ca}^{2+}+\mathrm{Mg}^{2+}\right) / \mathrm{HCO}^{3-}$ ratio is used to define the sources of $\mathrm{Ca}^{2+}$ and $\mathrm{Mg}^{2+}$ in groundwater (Fig 4b). If $\mathrm{Ca}^{2+}, \mathrm{Mg}^{2+}$ and $\mathrm{HCO}^{3-}$ in waters are derived from carbonate minerals, the ratio of $\left(\mathrm{Ca}^{2+}+\mathrm{Mg}^{2+}\right) / \mathrm{HCO}^{3-}$ should equal to 1 (Zhang et al, 2015). Fig 4b shows that the ratio was not equal to 1 , so can be known that the source of $\mathrm{Ca}^{2+}$ and $\mathrm{Mg}^{2+}$ come from another source. Fig $4 \mathrm{C}$ shows that $\mathrm{Na}^{+}$and $\mathrm{K}^{+}$are relatively more abundant than $\mathrm{Ca}^{2+}$ and $\mathrm{Mg}^{2+}$. It was associated with volcanic terrain and sourced from the weathering of K-feldspar and Plagioclase. $\mathrm{Na}+\mathrm{Cl} / \mathrm{HCO}_{3}+\mathrm{SO}_{4}+\mathrm{Mg}$ - $\mathrm{Ca}$ graphic used to identify the mechanisms for obtaining cation exchange and adsorption. If there are cation exchange and adsorption, the point is close to the $1: 1$ line (Pazand et al, 2018). Fig $4 d$ shows $R^{2}=0,8126$ indicating there are different degrees of cation exchange adsorption in study area.
Gibbs plot shows as a function of the TDS that has the ability to provide information about the relative importance of the major natural mechanisms controlling groundwater chemistry and is extensively used to assess the functional sources of dissolved chemical constituents, such as precipitation dominance, rock dominance, and evaporation dominance (Pazand et al, 2018). Fig 5 shows that groundwater chemistry is mainly controlled by rock weathering and balance of evaporation-precipitation condition.

The chemical of groundwater including ion changing or chemistry reactions can be changed as time goes by. Next research needs to be done to know this changing in a certain period.

\subsection{Groundwater Assessment for Drinking Purpose}

Groundwater assessment for drinking purpose at research area is according to Indonesia Healthy Ministry regulation standard No. 492/MENKES/PER/IV/2010 (Table 2). There are 18 parameters which be used as references for this research. The 18 parameters including 7 physics and 11 chemical data. Laboratory analysis result shows there are value differences which very contrast on some parameters. The parameters are colour, muddiness, TDS, Fe, $\mathrm{pH}, \mathrm{Mn}$, and $\mathrm{NO}_{3}$ (Table 3 and Table 4). These contrast differences in value are evidently out of standard range which had been set. These are occurred on some samples were $A 1, A 2, A 3$, A4, A5, A7, A8, A9 (Table 5).

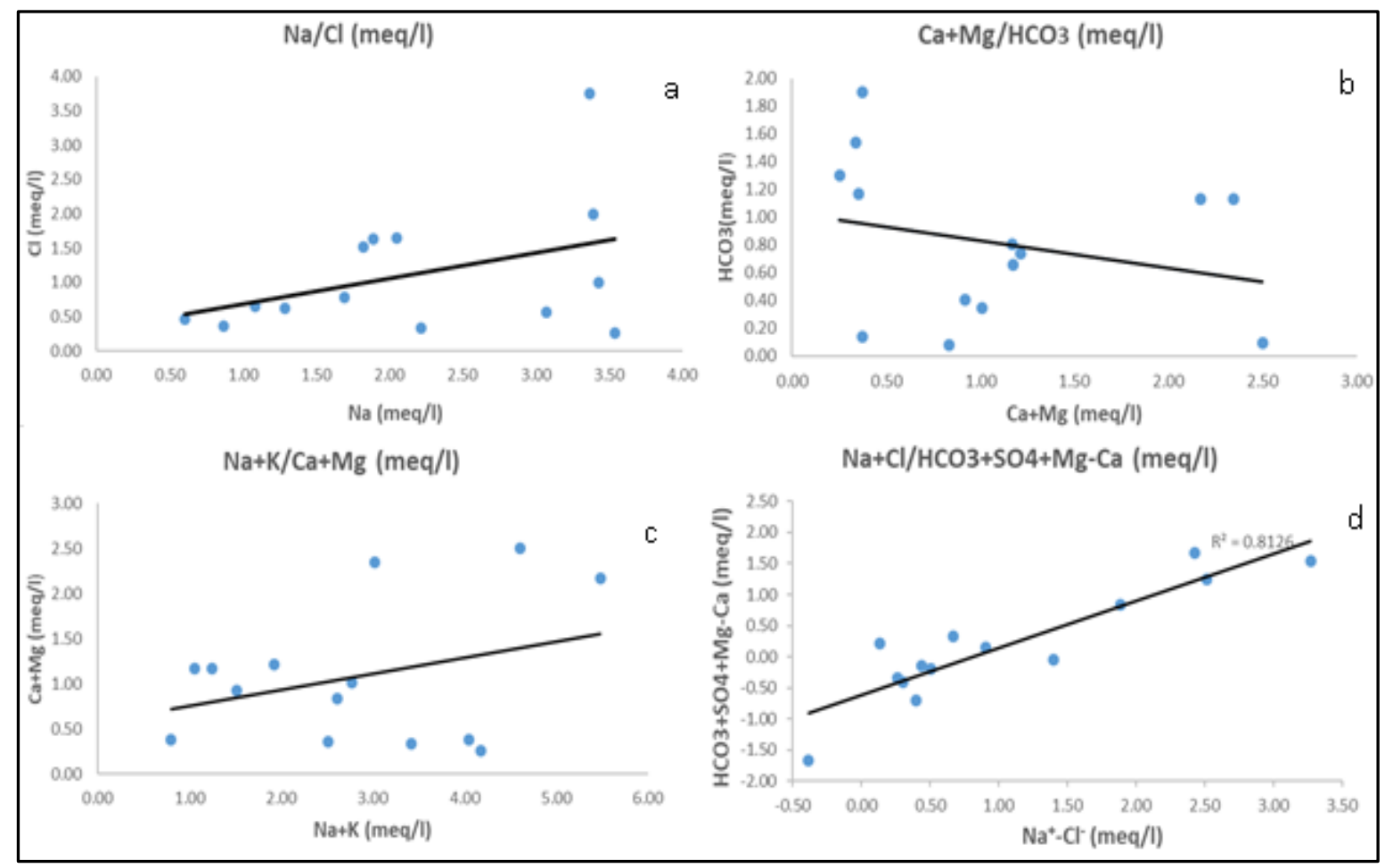

Fig. 4. Ions scatter diagram of groundwater in the study area. 


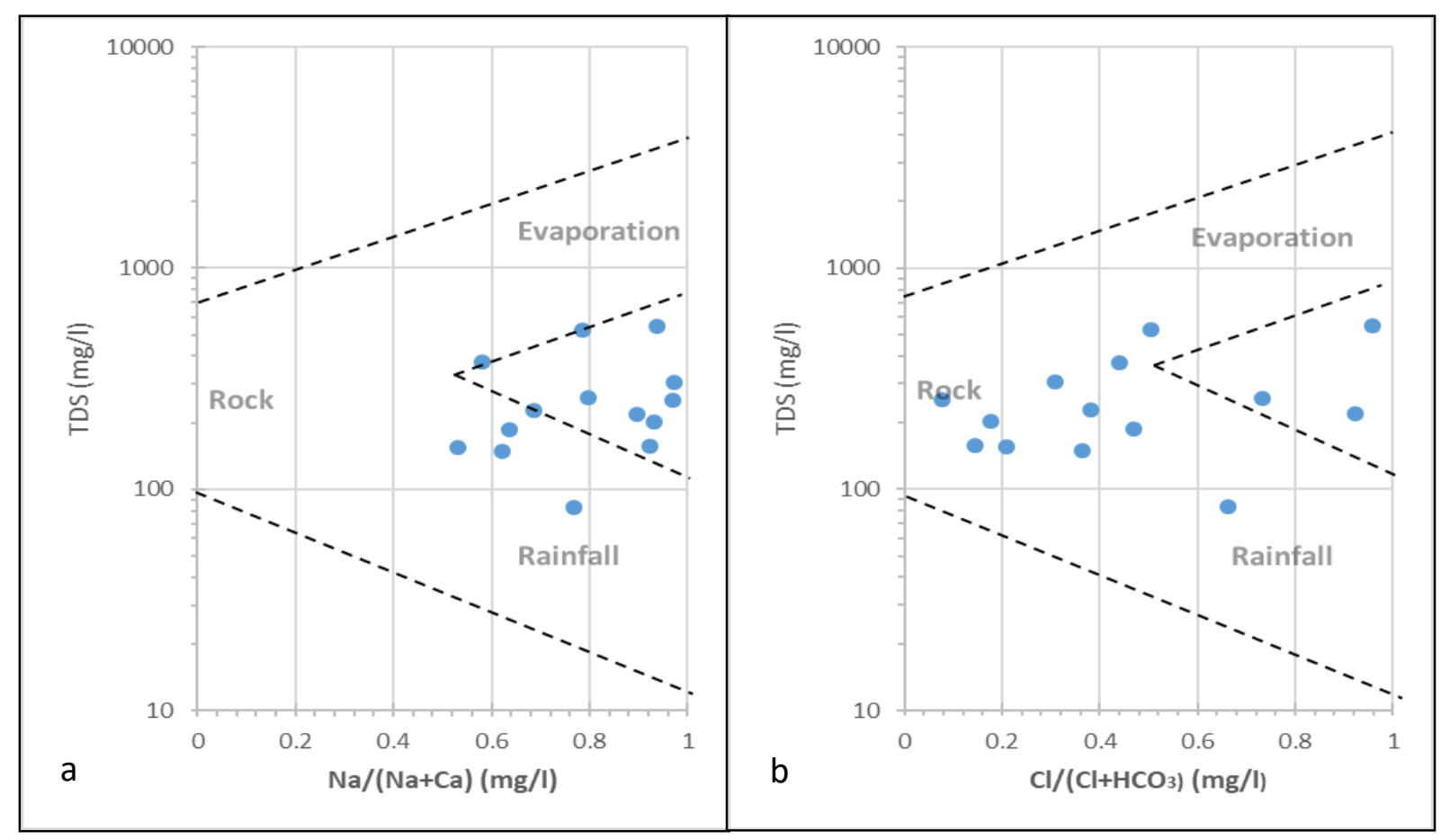

Fig. 5. Relationships between ion concentrations for $\mathrm{Na}^{+}, \mathrm{Ca}^{2+}, \mathrm{Cl}^{-} \mathrm{HCO}^{3-}$ with TDS.

Colour and Muddiness have straight correlation according to data. The samples which had very high value

for colour are A4 (10 Pt. Co), and A8 (20 Pt. Co). The colour for A4 is yellow to red, it is affected by iron contamination and the colour for A8 is yellow to brownish it might be affected by iron mixing with organic matter. This result also occurred for muddiness parameter. Both samples also had high muddiness above standard, A4 (29,7 NTU) and A8 (65,4 NTU). Besides that, A7 (15,7 NTU) and A9 (7,66 NTU) also has high value but not higher than A4 and A8.

TDS depends mainly on the concentration of major ions such as $\mathrm{HCO}^{-}, \mathrm{SO}^{2-}, \mathrm{Cl}^{-} \mathrm{Mg}^{2+}$, and $\mathrm{Na}^{+}$(Chang and Wang, 2010). The high value above standard for TDS parameter come from A3 $(526 \mathrm{mg} / \mathrm{L})$ and A5 (525 $\mathrm{mg} / \mathrm{L}$ ). These results are affected because of $\mathrm{Cl}^{-}$and $\mathrm{SO}_{4}{ }^{2-}$ ions that its source from tuff as volcanic deposits and/or anthropogenic contamination.

The rise in iron contamination in natural water sources is linked to various processes, which including oxidation-reduction reactions from weathering of iron rich minerals, microbiological activities, and anthropogenic iron contaminations (Sarkar and Shekhar, 2018). There are two samples that have high value of $\mathrm{Fe}, \mathrm{A} 4(1,04 \mathrm{mg} / \mathrm{L})$ and $\mathrm{A} 8$ $(0,581 \mathrm{mg} / \mathrm{L})$. These only about $14 \%$ of all samples. This percentage shows that this as a local phenomenon because of uncovering all area. This phenomenon shows the high value of Fe is effected by anthropogenic iron contaminations.

The presence of $\mathrm{Mn}$ as same as with $\mathrm{Fe}$. Both presence due to either natural or anthropogenic sources (Corniello and Ducci, 2014). Natural sources come from weathering of minerals (pyroxenes, amphiboles, biotite, magnetite and in particular, olivine). While, anthropogenic sources come from wastewater discharge, dust and aerosols during metallurgical processing, coal combustion, corrosion of water pumping infrastructure and transport of minerals or contamination associated with mining activities (Esteller et al, 2017). The main factors controlling the presence of these elements in water are $\mathrm{pH}$, redox conditions and presence of organic or inorganic ligands (Corniello and Ducci, 2014). An acidic $\mathrm{pH}$ indicates that both ions are mobile, while a more neutral $\mathrm{pH}$ indicates that mobility is determined by redox conditions (Esteller et al, 2017). The Table 4 shows that $\mathrm{A} 2$ and $\mathrm{A} 5$ have direct correlation with $\mathrm{pH}$ value (acid) so could be concluded that $\mathrm{Mn}$ source comes from anthropogenic not by redox conditions.

Typical sources of nitrate in groundwater are mainly related to agricultural and domestic wastewater discharges (Andersen and Kristiansen, 1983). There were three samples which had higher result than standard, A2 (59,8 mg/L), A3 (55,7 mg/L), and A5 (114 mg/L). These covered about $21 \%$ of all samples. These results might be had direct correlation with research area that mostly was covered by agriculture about $60 \%$

The samples which contain $\mathrm{pH}$ out of standard are $\mathrm{A} 1, \mathrm{~A} 2$, and $\mathrm{A} 5$. All of them contain $\mathrm{pH}$ under $6 . \mathrm{A} 2$ and A5 might be affected by dominance the presence of $\mathrm{Mn}$ and $\mathrm{Fe}$. Al might be affected by intake $\mathrm{CO}_{2}$ from Atmosphere.

Table 5 shows that almost all samples especially which are taken from dig wells cannot be used for drinking water but samples which are taken from drill wells can be used for drinking purpose. This result also gives information that groundwater from unconfined aquifer is not good for drinking purpose but groundwater from confined aquifer is good for drinking purpose. 
Table 2. The groundwater physics and chemistry standard for drinking purpose based on No. 492/MENKES/PER/IV/2010.

\begin{tabular}{|c|c|}
\hline Parameters & Standard \\
\hline Smell & no smell \\
\hline Flavour & no flavour \\
\hline Colour (Pt.Co) & 15 \\
\hline Muddiness (NTU) & 5 \\
\hline $\mathrm{EC}(\mu \mathrm{S} / \mathrm{cm})$ & no information \\
\hline TDS (mg/L) & 500 \\
\hline Temp $\left({ }^{\circ} \mathrm{C}\right)$ & $\pm 3^{\circ} \mathrm{C}$ \\
\hline $\mathrm{Fe}(\mathrm{mg} / \mathrm{L})$ & 0,3 \\
\hline $\mathrm{F}(\mathrm{mg} / \mathrm{L})$ & 1,5 \\
\hline $\mathrm{pH}$ & $6,5-8,5$ \\
\hline $\mathrm{Mn}(\mathrm{mg} / \mathrm{L})$ & 0,4 \\
\hline $\mathrm{NO}_{3}(\mathrm{mg} / \mathrm{L})$ & 50 \\
\hline $\mathrm{NO}_{2}(\mathrm{mg} / \mathrm{L})$ & 3 \\
\hline $\mathrm{Cl}(\mathrm{mg} / \mathrm{L})$ & 250 \\
\hline $\mathrm{SO}_{4}(\mathrm{mg} / \mathrm{L})$ & 250 \\
\hline $\mathrm{Na}(\mathrm{mg} / \mathrm{L})$ & 200 \\
\hline $\mathrm{CaCO}_{3}\left(\mathrm{mg} / \mathrm{L} \mathrm{CaCO}_{3}\right)$ & 500 \\
\hline $\mathrm{Pb}(\mathrm{mg} / \mathrm{L})$ & 0,01 \\
\hline
\end{tabular}

Table 3. The physical data of all samples at research area.

\begin{tabular}{cllllllll}
\hline $\begin{array}{c}\text { Samples } \\
\text { Code }\end{array}$ & $\begin{array}{c}\text { Wells } \\
\text { Type }\end{array}$ & Smell & Taste & $\begin{array}{c}\text { Colour } \\
(\text { Pt. Co) }\end{array}$ & $\begin{array}{c}\text { Muddiness } \\
(\text { NTU) }\end{array}$ & $\begin{array}{c}\text { EC } \\
(\mu \mathrm{S} / \mathrm{cm})\end{array}$ & $\begin{array}{c}\text { TDS } \\
(\mathrm{mg} / \mathrm{L})\end{array}$ & $\begin{array}{c}\text { Temp } \\
\left({ }^{\circ} \mathrm{C}\right)\end{array}$ \\
\hline A1 & Dig & No & No & 5 & 2,41 & 433 & 259 & 25,7 \\
\hline A2 & Dig & No & No & 5 & 0,07 & 365 & 219 & 25,8 \\
\hline A3 & Dig & No & No & 5 & 1,51 & 752 & 526 & 25,7 \\
\hline A4 & Dig & Yes & Yes & 10 & 29,7 & 248 & 149 & 25,7 \\
\hline A5 & Dig & No & No & 5 & 4,94 & 778 & 545 & 25,7 \\
\hline A6 & Dig & No & No & 5 & 2,48 & 222 & 155 & 25,7 \\
\hline A7 & Dig & No & No & 5 & 15,7 & 535 & 375 & 25,7 \\
\hline A8 & Dig & Yes & Yes & 20 & 65,4 & 138 & 83 & 24,8 \\
\hline A9 & Dig & No & No & 5 & 7,66 & 326 & 228 & 25,7 \\
\hline B1 & Drill & No & No & 5 & 0,79 & 435 & 304 & 25,9 \\
\hline B2 & Drill & No & No & 5 & 1,14 & 311 & 187 & 25,8 \\
\hline B3 & Drill & No & No & 5 & 0,81 & 339 & 203 & 25,8 \\
\hline B4 & Drill & No & No & 5 & 2,3 & 423 & 253 & 24,7 \\
\hline B5 & Drill & No & No & 5 & 0,84 & 261 & 157 & 25,8 \\
\hline
\end{tabular}


Table 4. The chemistry data of all samples which taken at research area.

\begin{tabular}{|c|c|c|c|c|c|c|c|c|c|c|c|c|}
\hline $\begin{array}{l}\text { Samples } \\
\text { Code }\end{array}$ & $\begin{array}{l}\text { Well } \\
\text { S } \\
\text { Type }\end{array}$ & $\begin{array}{c}\mathrm{Fe} \\
(\mathrm{mg} / \mathrm{L}\end{array}$ & $\underset{(\mathrm{mg} / \mathrm{L}}{\mathrm{F}}$ & $\mathrm{pH}$ & $\begin{array}{c}\mathrm{Mn} \\
(\mathrm{mg} / \mathrm{L}\end{array}$ & $\begin{array}{c}\mathrm{NO}_{3} \\
(\mathrm{mg} / \mathrm{L} \\
)\end{array}$ & $\begin{array}{c}\mathrm{NO}_{2} \\
(\mathrm{mg} / \mathrm{L}\end{array}$ & $\underset{(\mathrm{mg} / \mathrm{L}}{\mathrm{Cl}}$ & $\begin{array}{c}\mathrm{SO}_{4} \\
(\mathrm{mg} / \mathrm{L}\end{array}$ & $\begin{array}{c}\mathrm{Na} \\
(\mathrm{mg} / \mathrm{L}\end{array}$ & $\begin{array}{c}\mathrm{CaCO}_{3} \\
(\mathrm{mg} / \mathrm{L} \\
\mathrm{CaCO}_{3} \\
)\end{array}$ & $\begin{array}{c}\mathrm{Pb} \\
(\mathrm{mg} / \mathrm{L})\end{array}$ \\
\hline $\mathrm{A} 1$ & Dig & 0,01 & 0,543 & 5,86 & $\varangle, 2$ & 45,2 & 0,3 & 57,7 & 15,9 & 43,5 & 50,5 & $<0,001$ \\
\hline $\mathrm{A} 2$ & Dig & 0,01 & 0,063 & 5,3 & 0,458 & 59,8 & 0,006 & 58,6 & 2,76 & 47,1 & 42 & $<0,001$ \\
\hline A3 & Dig & 0,045 & 0,273 & 7,1 & $\varangle 0,2$ & 55,7 & 0,004 & 70,6 & 48 & 78 & 110 & $<0,001$ \\
\hline A4 & Dig & 1,04 & 0,123 & 6,43 & $\varangle 0,2$ & 7,41 & 0,004 & 22,9 & 17,8 & 24,9 & 59 & $<0,001$ \\
\hline A5 & Dig & 0,01 & 0,255 & 5,54 & 1,11 & 114 & 0,665 & 133 & 35,7 & 77,4 & 126 & $<0,001$ \\
\hline A6 & Dig & 0,01 & 0,162 & 6,53 & $\varangle 0,2$ & 6,85 & 0,004 & 12,9 & 7,89 & 20 & 59 & $<0,001$ \\
\hline A7 & Dig & 0,232 & 0,255 & 6,5 & $\varangle, 2$ & 22,7 & 0,117 & 53,9 & 38,8 & 41,9 & 118 & $<0,001$ \\
\hline A8 & Dig & 0,581 & 0,233 & 6,64 & $\varangle 0,2$ & 5,45 & 0,004 & 16,6 & 21,5 & 13,9 & 19 & $<0,001$ \\
\hline A9 & Dig & 0,01 & 0,181 & 6,58 & $\varangle, 2$ & 25,9 & 0,073 & 27,8 & 30,3 & 38,9 & 61 & $<0,001$ \\
\hline B1 & Drill & 0,01 & 0,409 & 7,06 & $\varangle 0,2$ & 3,88 & 0,004 & 35,5 & 29,8 & 78,8 & 12,5 & $<0,001$ \\
\hline B2 & Drill & 0,01 & 0,103 & 6,33 & $\varangle 0,2$ & 16,9 & 0,004 & 21,9 & 41 & 29,6 & 46,3 & $<0,001$ \\
\hline B3 & Drill & 0,172 & 0,457 & 7,15 & $\varangle 0,2$ & 2,93 & 0,004 & 19,9 & 1,93 & 70,7 & 17 & $<0,001$ \\
\hline B4 & Drill & 0,01 & 0,574 & 7,38 & $\varangle 0,2$ & 2,29 & 0,391 & 9,58 & 1 & 81,4 & 19 & $<0,001$ \\
\hline B5 & Drill & 0,01 & 0,291 & 6,83 & $\varangle 0,2$ & 2,09 & 0,004 & 11,9 & 1,41 & 51,0 & 18 & $<0,001$ \\
\hline
\end{tabular}

Table 5. List of samples out of standard

\begin{tabular}{llll}
\hline \multicolumn{1}{c}{ Parameters } & \multicolumn{1}{c}{ Min } & \multicolumn{1}{c}{$\begin{array}{c}\text { Ma } \\
\text { X }\end{array}$} & \multicolumn{1}{c}{$\begin{array}{c}\text { Samples out of } \\
\text { standard }\end{array}$} \\
\hline Colour (Pt.Co) & 5 & 20 & $\mathrm{~A} 4, \mathrm{~A} 8$ \\
Muddiness (NTU) & 0,07 & 65,4 & $\mathrm{~A} 4, \mathrm{~A} 7, \mathrm{~A} 8, \mathrm{~A} 9$ \\
TDS (mg/L) & 83 & 545 & $\mathrm{~A} 3, \mathrm{~A} 5$ \\
$\mathrm{Fe}(\mathrm{mg} / \mathrm{L})$ & 0,01 & 1,04 & $\mathrm{~A} 4, \mathrm{~A} 8$ \\
$\mathrm{pH}$ & 5,3 & 7,38 & $\mathrm{~A} 1, \mathrm{~A} 2, \mathrm{~A} 5$ \\
$\mathrm{Mn} \mathrm{(mg/L)}$ & 0,2 & 1,11 & $\mathrm{~A} 2, \mathrm{~A} 5$ \\
$\mathrm{NO}_{3}$ (mg/L) & 2,09 & 114 & $\mathrm{~A} 2, \mathrm{~A} 3, \mathrm{~A} 5$ \\
\hline
\end{tabular}

\section{Conclusions}

From research at ITERA campus area and its surroundings then can be concluded as follow:

a. Groundwater consist of five groundwater facieses, they are Facies $\mathrm{Na}-\mathrm{HCO} 3-\mathrm{Cl}(35,71 \%$, Facies $\mathrm{Na}-\mathrm{Cl}$ $(21,43 \%$, Facies Na-HCO3 $(21,43 \%$, Facies Na-SO4$\mathrm{Cl}(14,29 \%)$, and Facies Ca-Mg-HCO3 $(7,14 \%$.

b. $\mathrm{X}-\mathrm{Y}$ plots show that $\mathrm{Na}^{+}$and $\mathrm{K}^{+}$at research area come from weathering of silicate minerals. Gibbs plot shows that there is another factor that controls groundwater chemistry in addition to effect from rocks weathering. The factor is a balance of evaporation-precipitation condition.

c. Groundwater which comes from unconfined aquifer (dig wells) is not proper for drinking purpose because it has been polluted by effect of human activities. Besides that, well condition without roof or cap makes groundwater be contaminated by precipitation easily. Precipitation can makes $\mathrm{pH}$ groundwater decreasing.

d. Groundwater which comes from confined aquifer with depth $\geq 40 \mathrm{~m}$ and closed well condition (drill well) is a good source for drinking purpose.

\section{Acknowledgements}

The Authors would like to give great thankyou to Kemenristekdikti for its financial support through Penelitian Dosen Pemula scheme (contract number: 007/SP2H/LT/DRPM/2018) for the 2018 activities so we could do this research fluently. The authors al so would like to give thank you to ITERA for the permission to accommodate the research.

\section{References}

Andersen, L.J., Kristiansen, H., 1983. Nitrate in groundwater and surface water related to land use in the Karup Basin, Denmark. Environ. Geol. 5, 207-212. https://doi.org/10.1007/BF02414865

Badan Standarisasi Nasional, 2008. Air dan air limbah - Bagian 58: Metoda pengambilan contoh air tanah.

Chang, J., Wang, G., 2010. Major ions chemistry of groundwater in the arid region of Zhangye Basin, northwestern China. Environ. Earth Sci. 61, 539-547. https://doi.org/10.1007/s12665-009-0364-2

Corniello, A., Ducci, D., 2014. Hydrogeochemical characterization of the main aquifer of the "Litorale Domizio-Agro Aversano NIPS" (Campania - southern Italy). J. Geochemical Explor. 137, 1-10. https://doi.org/10.1016/j.gexplo.2013.10.016

Esteller, M. V., Kondratenko, N., Expósito, J.L., Medina, M. Martin del Campo, M.A., 2017. Hydrogeochemical characteristics of a volcanic-sedimentary aquifer with special emphasis on Fe and Mn content: A case study in Mexico. J. Geochemical Explor. 180, 113-126. https://doi.org/10.1016/j.gexplo.2017.06.002

Jeevanandam, M., Kannan, R., Srinivasalu, S., Rammohan, V. 2007. Hydrogeochemistry and groundwater quality assessment of lower part of the Ponnaiyar River Basin, Cuddalore district, South India. Environ. Monit. Assess. 132, 263-274. https://doi.org/10.1007/s10661-006-9532y

Mangga, S.A; Amirudin; Suwarti, T; Gafoer, S.S., 1993. Peta Geologi Lembar TanjungKarang, Sumatera. pp. 3-13.

Meybeck, M., 1987. Global chemical weathering of surficial rocks estimated from river dissolved loads. Am. J. Sci. 
https://doi.org/10.2475/ajs.287.5.401

Pazand, K., Khosravi, D., Ghaderi, M.R., Rezvanianzadeh, M.R., 2018. Identification of the hydrogeochemical processes and assessment of groundwater in a semi-arid region using major ion chemistry: A case study of Ardestan basin in Central Iran. Groundw. Sustain. Dev. 6, 245-254. https://doi.org/10.1016/j.gsd.2018.01.008

Sarkar, A., Shekhar, S., 2018. Iron contamination in the waters of Upper Yamuna basin. Groundw. Sustain. Dev. https://doi.org/10.1016/j.gsd.2017.12.011

Setiadi, H; Ruhijat, S., 1993. Hydrogeological Map, Tanjung Karang Sheet 1:250.000.

Setiawan, M.R., Badri, R.M., Singarimbun, A., Sains, J., Fisika, P. Fisika, D., 2017. Kajian Awal Pendugaan Akuifer Air Tanah di Kampus ITERA dengan Metode Geolistrik Konfigurasi Schlumberger. J. Sci. Appl. Teknol. Sumatera 2, 40-46.

Wen, X., Wu, Y., Su, J., Zhang, Y., Liu, F., 2005. Hydrochemical characteristics and salinity of groundwater in the Ejina Basin, Northwestern China. Environ. Geol. 48, 665-675. https://doi.org/10.1007/s00254-005-0001-7
Yang, Q., Li, Z., Ma, H., Wang, L., Martín, J.D., 2016. Identification of the hydrogeochemical processes and assessment of groundwater quality using classic integrated geochemical methods in the Southeastern part of Ordos basin, China. Environ. Pollut. 218, 879-888. https://doi.org/10.1016/j.envpol.2016.08.017

Zhang, F., Jin, Z., Yu, J., Zhou, Y., Zhou, L., 2015. Hydrogeochemical processes between surface and groundwaters on the northeastern Chinese Loess Plateau: Implications for water chemistry and environmental evolutions in semi-arid regions. J. Geochemical Explor. 159 ,

115-128.

https://doi.org/10.1016/j.gexplo.2015.08.010

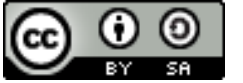

(c) 2019 Journal of Geoscience, Engineering Environment and Technology. All rights reserved. This is an open access article distributed under the terms of the CC BY-SA License (http://creativecommons.org/licenses/by-sa/4.0/). 